\title{
Spatial and temporal variation in weather events critical for boreal agriculture: III Frost and winter time fluctuation
}

\author{
Pirjo Peltonen-Sainio ${ }^{1}$, Pentti Pirinen², Mikko Laapas², Hanna M. Mäkelä², Hannu Ojanen³ ${ }^{3}$ Ari Venäläinen² \\ ${ }^{1}$ Natural Resources Institute Finland (Luke), Management and Production of Renewable Resources, Fl-31600 Jokioinen, Finland \\ ${ }^{2}$ Finnish Meteorological Institute, PL 503, Fl-00560 Helsinki, Finland \\ ${ }^{3}$ Natural Resources Institute Finland (Luke), Green Technology, FI-31600 Jokioinen, Finland \\ e-mail: pirjo.peltonen-sainio@luke.fi
}

\begin{abstract}
In the boreal zone of Europe, differences between the four seasons are considerable. Also, the within-season variation in climatic conditions is substantial. This has many impacts on agriculture that are exceptional when compared to any other environmental zone in Europe. All the meteorological data were based on weather observations made by the Finnish Meteorological Institute. Likelihood (\%) for soil frost $\left(\leq 0^{\circ} \mathrm{C}\right.$ at $20 \mathrm{~cm}$ soil depth) at nine weather stations, and late snow cover $(>1 \mathrm{~cm})(10 \mathrm{~km} \times 10 \mathrm{~km}$ grid) were estimated for late spring. Probabilities (\%) of night frost at the ground surface (March-September) were calculated at nine weather stations by frequencies of the lowest observed night-time temperature: a) between -2 and $-5^{\circ} \mathrm{C}$ (mild), b) $\leq-5^{\circ} \mathrm{C}$ (moderate) and $\mathrm{c}$ ) $\leq-9^{\circ} \mathrm{C}$ (severe). Also, the probabilities (\%) of night frost in mid-summer were estimated $\left(\leq-1{ }^{\circ} \mathrm{C}\right.$ for at least five hours). Furthermore, a significant shift from mild to below-freezing conditions was measured in winter as a period of at least ten days with daily maximum temperatures above $0^{\circ} \mathrm{C}$ followed by at least a 10-day period with daily mean temperatures below $-5^{\circ} \mathrm{C}$ in order to characterize high fluctuating winter conditions. All these except late snow cover constitute high risks to crop production. Deep soil frost may postpone sowings, while in advanced springs, night frost may cause damage. For winter crops and perennials, shifts from mild to cold spells outside the growing season are particularly detrimental. Again the data may have many other applications beyond the assessments highlighted in this paper.
\end{abstract}

Key words: crop, frost, overwintering, probability, sowing time, spatial variation

\section{Introduction}

Finland's climate is characterized by distinctly different seasons: the winter mean temperature remains below zero in the whole country, while in summer mean temperatures are typically approx. $20^{\circ} \mathrm{C}$ higher (Pirinen et al. 2012). These climatological extremes take turns through the transition seasons. The thermal growing season, i.e., the time when the daily mean temperature exceeds $5^{\circ} \mathrm{C}$, starts at the end of April according to the long-term mean in the southernmost regions of Finland and approximately one month later in the northern parts of the country. However, since the onset of the thermal growing season, there is typically a lag-period of even up to several weeks until the soil and climatic conditions are sufficiently favourable for extensive sowings (Peltonen-Sainio and Jauhiainen 2014).

Due to the very short growing season and harsh winter conditions in Finland, early maturing crops and cultivars are grown and the spring-sown grain and seed crops are favoured at the expense of overwintering crops. Furthermore, commercial fruit, e.g. apple (Malus domestica Borkh.) production is limited to the most favourable regions (Kaukoranta et al. 2010). Long days typical of high-latitude growing seasons substantially enhance the rate of development of many crops (Peltonen-Sainio and Rajala 2007), which again means that the time window is narrow for practically all the field operations to gain the optimal outcome and efficacy. This again may be further challenged by variable and unfavourable weather events.

Early sowing enables utilization of as long a part of the short thermal growing season as possible. Delayed sowing was estimated to reduce grain yield of cereals by 20-35 kg ha-1 $\mathrm{d}^{-1}$ (averaging $1 \% \mathrm{~d}^{-1}$ ) and rapeseed by even up to $40 \mathrm{~kg} \mathrm{ha}^{-1} \mathrm{~d}^{-1}\left(\geq 2 \% \mathrm{~d}^{-1}\right)$ (Hakala et al. 2012, Peltonen-Sainio and Jauhiainen 2014, Peltonen-Sainio et al. $2016 \mathrm{a}$ ). Furthermore, late sowing may challenge harvesting, when associated with cool temperatures during the growing season (Peltonen-Sainio and Jauhiainen 2014).

For successful sowing in spring, the soil needs to become sufficiently dry and warm to favour seed germination and e.g. avoid harmful microbe infestations reducing the number of emerged seedlings (Pahkala et al. 2006). Crop management and weather conditions that favour early and even germination, seedling emergence and plant stand establishment facilitate the formation of high yields (Rajala et al. 2011). Persistence of snow cover and/ or soil frost may vary from one year to another depending on region (Venäläinen et al. 2001, Jylhä et al. 2008). 
For example, the winter of 2014-2015 was very mild. In Jokioinen (60.8N, 23.5E), there was a soil frost only in January and February with the maximum depth at around $10 \mathrm{~cm}$. In an average winter, the soil frost in Jokioinen lasts from early November to late April, having a maximum depth of about $50 \mathrm{~cm}$. In an exceptionally harsh winter, the soil frost lasts from October to mid-May and penetrates the soil down to a $100 \mathrm{~cm}$ depth (Suppl. Fig. S1). On the other hand, the mean annual maximum soil frost depths are roughly $150 \mathrm{~cm}$ for northern Finland, but less than $50 \mathrm{~cm}$ for south-eastern Finland (Huttunen and Soveri 1993).

Depth and longevity of the soil frost are critical factors determining the first potential time for sowing. Weather conditions such as temperature and precipitation (Peltonen-Sainio et al. 2016b, 2016c) may again either enable or postpone sowings depending on how well they favour operations, but also depending on production system, especially tillage method (Känkänen et al. 2011, Soane et al. 2012). As night frosts are often experienced after sowings under high latitude conditions, consideration of the risk for night frost may also be critical for the timing of sowing depending on crop. Spring cereals can tolerate even severe night frosts at the seedling stage, while seedlings of turnip rape (Brassica rapa L.), oilseed rape (B. napus L.), sugar beet (Beta vulgaris L.) and pea (Pisum sativum L.) are sensitive to losses or may suffer total failures as may many horticultural crops. These issues are thoroughly assessed in the paper of Lindén et al. (1999).

An assessment of historical data has revealed that especially simultaneous and/or successive adverse weather events have not only resulted in crop losses but also total crop failures. This has occurred with an average frequency of one extensive failure per decade (Peltonen-Sainio and Niemi 2012). Often these failures in the past are associated with markedly postponed spring sowings associated with cool and rainy conditions during the growing season. This sub-paper is the third one of the trilogy on climatic variability in Finland, and it concentrates on presenting the variation in spring soil frost, spring snow cover and the risk of night frost for the period from early March to late September. These all control the onset of sowings and early crop growth during the short growing season in Finland. Furthermore, we have characterized the likelihood of winter-time fluctuation from mild to cold spells that may endanger the overwintering of autumn sown and perennial crops. Thereby, we illustrate with some examples how the information available on these specific climatic event is applicable to agriculture, but the data as such also probably supports many other assessments related to agriculture and beyond.

\section{Materials and methods}

All meteorological data were based on weather observations made by the Finnish Meteorological Institute (FMI). All the data sets are as quality checked and stored in a climate database.

Soil frost data from nine weather stations of the Finnish Meteorological Institute (FMI) (for stations see Table 1) were available with recording periods of 18 to 43 years depending on station. The likelihood (\%) of soil frost (soil temperature $\leq 0^{\circ} \mathrm{C}$ ) at a $20 \mathrm{~cm}$ soil depth was determined in five day intervals covering the time period from 13th of April to 28th of May. Likelihood was simply determined as a proportion of years with soil frost observed (at least one day soil temperature below the threshold) during each five day interval.

Table 1. Probabilities of late spring soil frost (measured soil temperature $\leq 0^{\circ} \mathrm{C}$ at $20 \mathrm{~cm}$ soil depth) at nine locations in Finland with the duration of each observation period (Finnish Meteorological Institute). Dot indicates no likelihood.

\begin{tabular}{|c|c|c|c|c|c|c|c|c|c|c|}
\hline \multirow[t]{2}{*}{ Location } & \multirow{2}{*}{$\begin{array}{l}\text { Latitude, } \\
\text { longitude }\end{array}$} & \multirow{2}{*}{$\begin{array}{c}\text { Observation } \\
\text { period }\end{array}$} & \multicolumn{8}{|c|}{ Probability for late soil frost } \\
\hline & & & 23 April & 28 April & 3 May & 8 May & 13 May & 18 May & 23 May & 28 May \\
\hline Mietoinen & $60.6 \mathrm{~N} 21.9 \mathrm{E}$ & $1988-2005$ & 0.28 & 0.06 & . & . & $\cdot$ & $\cdot$ & · & $\cdot$ \\
\hline Jokioinen & $60.8 \mathrm{~N} 23.5 \mathrm{E}$ & $1971-2013$ & 0.26 & 0.16 & 0.02 & . & . & . & . & $\cdot$ \\
\hline Kouvola & $60.7 \mathrm{~N} 26.8 \mathrm{E}$ & $1971-2013$ & 0.37 & 0.21 & 0.02 & . & . & . & . & . \\
\hline Seinäjoki & $62.9 \mathrm{~N} 22.5 \mathrm{E}$ & 1971-2011 & 0.32 & 0.20 & 0.10 & 0.05 & $\cdot$ & . & · & . \\
\hline Jyväskylä & $62.4 \mathrm{~N} 25.7 \mathrm{E}$ & $1975-2013$ & 0.95 & 0.90 & 0.67 & 0.46 & 0.21 & 0.13 & 0.05 & 0.05 \\
\hline Tohmajärvi & $62.2 \mathrm{~N} 30.3 \mathrm{E}$ & 1974-2011* & 0.27 & 0.21 & 0.12 & 0.09 & 0.03 & . & . & . \\
\hline Maaninka & $63.1 \mathrm{~N} 27.3 \mathrm{E}$ & $1971-2013$ & 0.74 & 0.56 & 0.35 & 0.12 & 0.02 & $\cdot$ & . & $\cdot$ \\
\hline Siikajoki & $64.7 \mathrm{~N} 25.1 \mathrm{E}$ & 1977-2003 & 0.82 & 0.63 & 0.56 & 0.30 & 0.15 & 0.04 & . & . \\
\hline Rovaniemi & $66.6 \mathrm{~N} 26.0 \mathrm{E}$ & $1975-2013$ & 0.66 & 0.66 & 0.63 & 0.53 & 0.40 & 0.13 & 0.03 & . \\
\hline
\end{tabular}


Late snow cover. The likelihood (\%) of late snow cover in spring exceeding $1 \mathrm{~cm}$ was estimated in five days intervals centred to 15 April to 25 May and was shown as a $10 \mathrm{~km} \times 10 \mathrm{~km}$ grid. Altogether, 473 stations were used for the analysis. The length of observation time series varied between 2 and 53 years. The first observations used were made in 1961 and the latest in 2013. The mean/median length of time series was 35.7/38 years (Suppl. Fig. S2). In the analysis, the snow depths available from all the available station for the date of interest, e.g. $15^{\text {th }}$ April, were first retrieved from the database. After that, the probability of the snow depth exceeding $1 \mathrm{~cm}$ was calculated for each day and station. The station-wise values were finally interpolated into a $10 \mathrm{~km} \times 10 \mathrm{~km}$ grid using the Kriging interpolation method (e.g. Aalto et al. 2013).

Night frost was as also described in Peltonen-Sainio et al. (2016a). Data was available for 15 weather stations, of which data from nine were used for this study to represent regional differences around the prime crop production region of Finland. Probabilities (\%) of freezing temperatures at the ground surface from 1 March to 30 September were estimated at five-day intervals on the basis of 43 years weather data with six to eight years less available from three stations. Three classes of night frost were defined, based on the lowest observed night-time temperature at the ground surface measured using the normal instruments used by the national meteorological services: between -2 and $-5{ }^{\circ} \mathrm{C}$ (mild), $\leq-5{ }^{\circ} \mathrm{C}$ (moderate) and $\leq-9{ }^{\circ} \mathrm{C}$ (severe). Furthermore, to estimate the probabilities of night frost in mid-summer ( 1 June to 31 July), freezing night-time temperatures of $\leq-1{ }^{\circ} \mathrm{C}$ that lasted at least five hours were studied for the same 15 weather stations. Because hourly measurements of the ground surface temperature were not available, the night frost was in this case estimated using temperature measurements in a screen located 2 metres above surface made every three hours and measurements of the lowest night-time temperature at the ground surface and at 2 metres height. Hourly temperature values were estimated from the three-hour values using the Fourier analysis.

Greatly fluctuating winter conditions were quantified as also described in Peltonen-Sainio et al. (2016a). In this context, the term "highly-fluctuating winter conditions" is taken to mean a significant shift from mild to below-freezing conditions, as follows: a period of at least ten days with daily maximum temperatures above $0^{\circ} \mathrm{C}$ was followed by at least a 10 -day period with daily mean temperatures below $-5^{\circ} \mathrm{C}$. The calculation procedure was as follows: 1 ) the number of mild days (daily maximum temperature above $0^{\circ} \mathrm{C}$ ) during the preceding 10 days including the day in question and the number of freezing days (daily mean temperature below $-5^{\circ} \mathrm{C}$ ) during the following 14 days including the day in question; 2 ) the frost sum (the sum of below zero temperatures) during the period day -40 to day $-10 ; 3)$ the heat sum during the period day -40 to day $-10 ; 4)$ the number of frost days during the period day -40 to day -10 ; and 5) the period was considered to be greatly fluctuating, if points 1 and 2 reached the 10 day demand and the preceding frost sum was higher than the heat sum. By comparing the frost and the heat sum, it was possible to judge whether the period occurred during thermal winter or not.

\section{Results}

Likelihood for the risk of late soil frost at a $20 \mathrm{~cm}$ soil depth was low $(\leq 2 \%)$ at the locations in the southern and south-west coastal prime production region in early May, but increased towards the northern dairy region, where it ranged e.g. from 5 to $53 \%$ at around 8 May - until the risk virtually shifted after mid-May (Table 1). Similar shifts from the southern, coastal locations to inland-northern locations were evident for the probability of late snow cover: by 5 May it was < $10 \%$ for the former locations, while up to $30-40 \%$ in the latter ones (Fig. 1). However, in mid-April the probabilities were still high for snow cover throughout the prime crop production region of Finland, with the lowest probabilities in the archipelago $(\leq 20 \%)$ and in the southern and south-western shoreline region, where it ranged from 10 to $60 \%$. Already by 10 May, the risk of $1 \mathrm{~cm}$ snow cover was negligible virtually throughout all of the agricultural regions of Finland except for Lapland, where the likelihood of snow cover still approached even $100 \%$. 

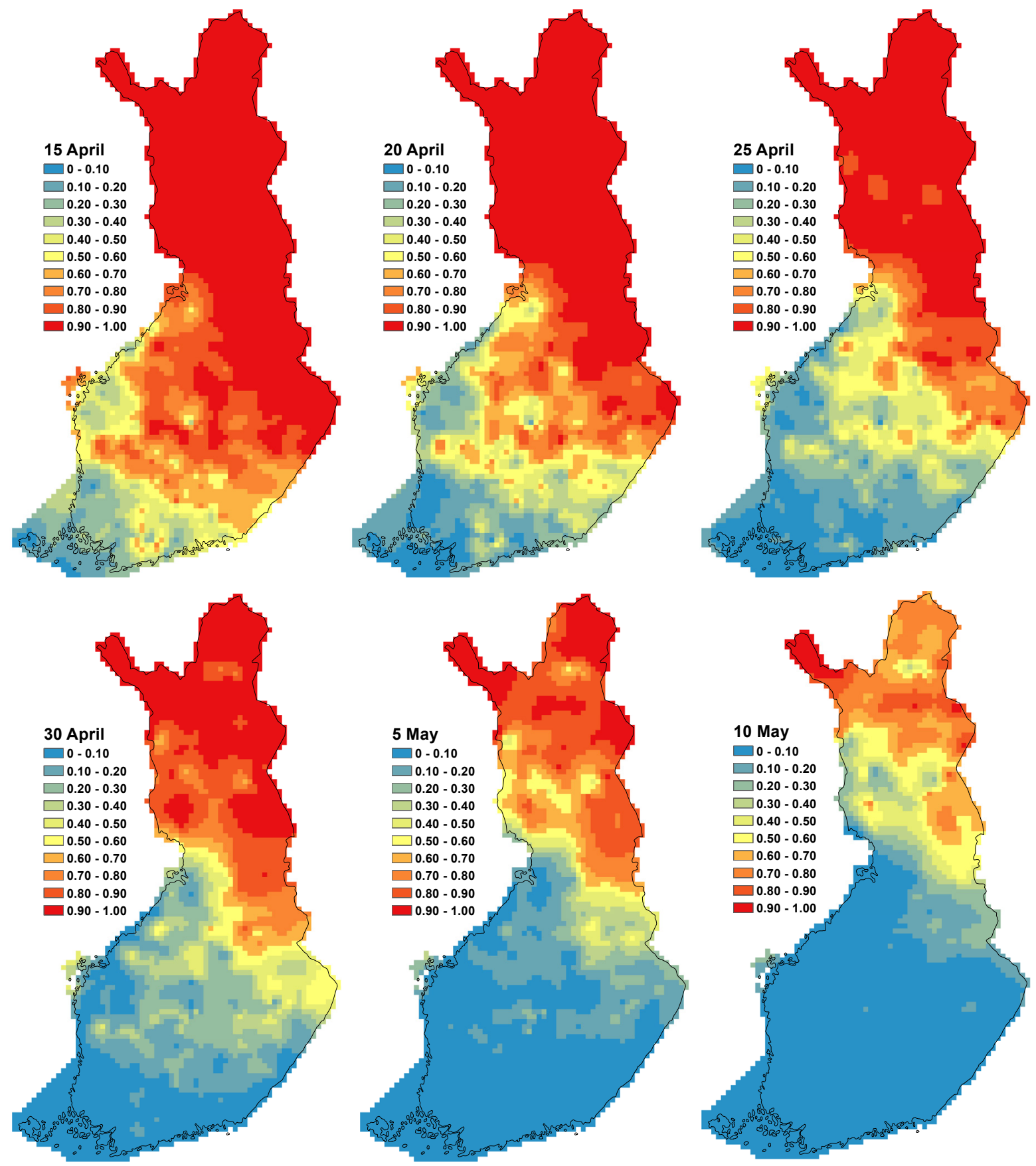

Fig. 1. Probabilities of late snow cover in a five-day intervals from 15 April to 10 May. Thereafter, the likelihood was negligible in agricultural regions

There were steep decreases in the risk of mild, moderate and severe night frost in spring depending on the region (Fig. 2). In general, the risk of severe night frost $\left(<-9^{\circ} \mathrm{C}\right)$ ended by early to late May, of moderate frost $\left(<-5^{\circ} \mathrm{C}\right)$ by mid-June and of mild frost (between -2 and $-5^{\circ} \mathrm{C}$ ) by the end of June. In some locations such as Seinäjoki, Siikajoki and Rovaniemi, there was up to a $6 \%$ probability of mild night frost throughout the growing season. Again, in some locations such as Mietoinen, Kouvola and Maaninka, the night-frost-free period lasted for about one and a half months between late June and around mid-August. The probabilities of mild night frost occurring after sowings were often great, up to $30-50 \%$ and for moderate frost up to $30 \%$ depending on region. 
By the heading of winter rye, there was still a reasonable risk of mild and in some cases even moderate night frost in many southern and inland locations (Fig. 2), but hardly any at the heading of spring barley. For rapeseed, the risk of mild night frost was apparent only in the case of the very early onset of the flowering period. According to an additional assessment, risks of night frost of $\leq-1{ }^{\circ} \mathrm{C}$ that, however, lasts for at least five hours were clearly higher around the heading and/or flowering of the field crops than that of mild night frost (between -2 and $-5^{\circ} \mathrm{C}$ ) in the same time period.

At the meteorological stations from which the data were available for more than 50 years, the likelihood was highly variable during the period of June-July, as it was $22 \%$ for Jokioinen, $13 \%$ for Kouvola, 33\% for Jyväskylä, $2 \%$ for Maaninka and $11 \%$ for Rovaniemi. At the sowing of winter cereals or soon after, night frost became gradually more and more frequent - around mid-August in the southern regions and early August in the northern agricultural regions.
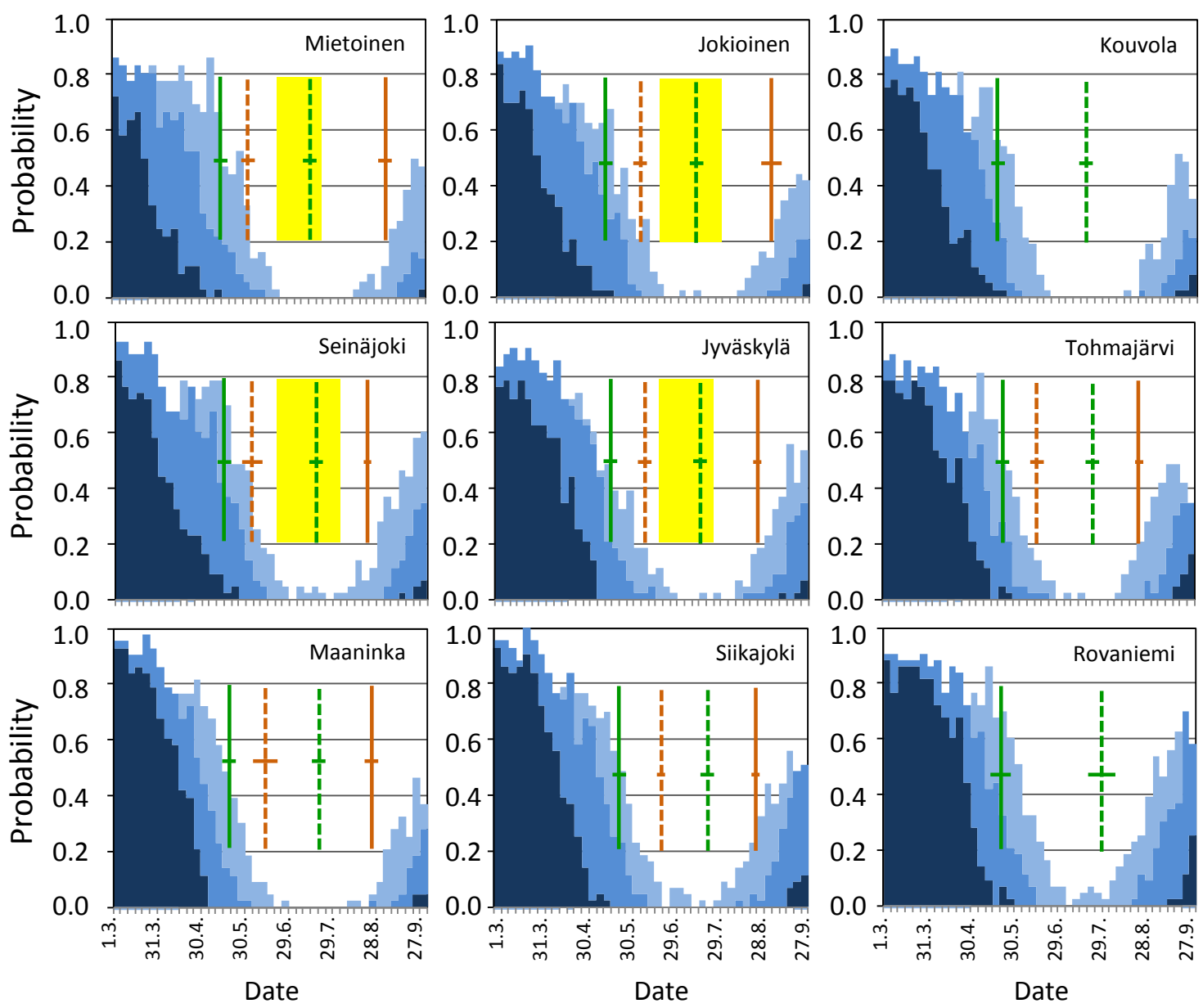

Fig. 2. Risk probabilities of night frost from 1 March to the end of September at nine locations in Finland. Light blue indicates mild $\left(-2\right.$ to $\left.-5^{\circ} \mathrm{C}\right)$, blue moderate $\left(\leq-5^{\circ} \mathrm{C}\right)$ and dark blue severe $\left(\leq-9^{\circ} \mathrm{C}\right)$ night frost. Green solid line indicates mean sowing time and green dashed line heading in spring cereals and the orange lines those for winter cereals. Yellow highlighted area indicates duration of flowering in rapeseed when appropriate. Latitudes and longitudes of each location are given in Table 1. 
Fluctuating winter conditions were most frequently experienced in the western coastal regions and eastern and south-eastern parts of the county with probabilities typically of 15-30\% (Fig. 3). On the other hand, in inland regions the likelihood was lower, usually around $10-15 \%$.

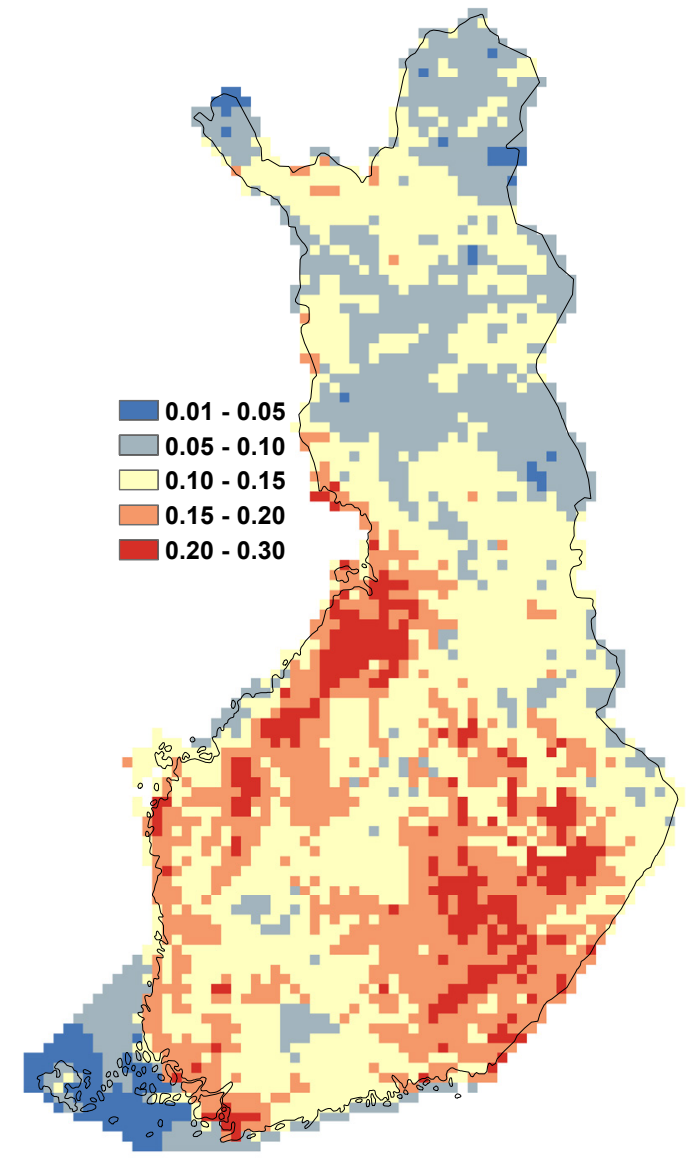

Fig. 3. Variation in probabilities of fluctuation from mild to cold spells outside the growing season

\section{Discussion}

Ecosystems and their functions at high latitudes are strongly steered by the steep differences between seasons and high inter- and intra-seasonal variation in climatic conditions. Though the agricultural systems and operations aim to control the impacts of the high climatic variability, agro-ecosystems are prone to climatic constraints with an outcome of high volatility in production volumes and increasingly in prices (Niemi and Ahlstedt 2011). In the first two papers of this trilogy, we concentrated on variation in temperature (Peltonen-Sainio et al. 2016b) and precipitation (Peltonen-Sainio et al. 2016c) from the beginning to the end of the thermal growing season, while this third paper expands the approach by demonstrating how soil frost and late snow cover in spring and early summer as well as night frost throughout the growing season vary and may thereby interfere with many of the processes of agro-ecosystems as well as agricultural operations. Again, we do not aim to be in any sense thorough with these assessments, but give some ideas about the applicability of these datasets with potentially high interest in agriculture but also beyond.

In addition to the very short growing season, sowing times fluctuate a great deal from one year to another in Finland with later sowing times from south to north and also from west to east (Table 2). However, later mean sowing times in a location is associated with lower standard deviation (except in the most northerly location, Rovaniemi), which is partly attributable to the increasingly narrow window for sowings in the shorter growing season of the northern areas (Peltonen-Sainio et al. 2009). However, also soil types differ, being clayey soils in the southern and 
western coastal regions (Lilja et al. 2009). In general, sowing times roughly followed the dynamics of loss of soil frost (Table 1) as did the likelihood of the late snow cover (Fig. 1). However, in the southern regions soil frost at a 20 $\mathrm{cm}$ depth was always lost more than 10 days and late snow cover almost one month prior to typical sowing time. Furthermore, in spite of even almost one month of annual range in sowing time, it never timely overlapped with soil frost: the earliest sowing time since 1970 was in early May, as was also the latest moment for soil frost in the least advanced springs. This was, however, opposite to some more northerly regions, especially Jyväskylä (Table 1).

Table 2. Variation in the onset of spring sowings on a large scale at nine locations in Finland. Data for 1970-2012 (PeltonenSainio and Jauhiainen 2014). SD (standard deviation); $95 \%$ Conf (95 \% confidence) limits of the mean

\begin{tabular}{|c|c|c|c|c|c|c|}
\hline \multirow{2}{*}{ Location } & \multirow{2}{*}{$\begin{array}{l}\text { Latitude, } \\
\text { longitude }\end{array}$} & \multicolumn{5}{|c|}{ Sowing day since 1 May } \\
\hline & & Mean & S.D. & Min & Max & $95 \%$ Conf \\
\hline Mietoinen & $60.6 \mathrm{~N} 21.9 \mathrm{E}$ & 14 & 5.5 & 2 & 24 & $12.3-15.6$ \\
\hline Jokioinen & $60.8 \mathrm{~N} \mathrm{23.5E}$ & 15 & 5.0 & 5 & 26 & 13.9-16.9 \\
\hline Kouvola & $60.7 \mathrm{~N} 26.8 \mathrm{E}$ & 17 & 5.1 & 6 & 27 & $15.7-18.7$ \\
\hline Seinäjoki & $62.9 \mathrm{~N} 22.5 \mathrm{E}$ & 17 & 4.4 & 9 & 26 & $16.0-18.6$ \\
\hline Jyväskylä & $62.4 \mathrm{~N} \mathrm{25.7E}$ & 18 & 4.4 & 9 & 27 & $16.9-19.5$ \\
\hline Tohmajärvi & $62.2 \mathrm{~N} 30.3 \mathrm{E}$ & 19 & 4.6 & 10 & 29 & $17.8-20.5$ \\
\hline Maaninka & $63.1 \mathrm{~N} 27.3 \mathrm{E}$ & 19 & 4.4 & 11 & 28 & $17.7-20.3$ \\
\hline Siikajoki & $64.7 \mathrm{~N} 25.1 \mathrm{E}$ & 19 & 5.4 & 10 & 31 & $17.0-20.2$ \\
\hline Rovaniemi & $66.6 \mathrm{~N} 26.0 \mathrm{E}$ & 21 & 7.0 & 8 & 38 & $18.8-22.9$ \\
\hline
\end{tabular}

Dynamics, depth and persistence of soil frost have many impacts on soil functions depending on soil type. In clay soils, soil frost is an important factor for the formation of soil aggregates (Edwards 2013). The characteristics of soil aggregates provided by climate and cultivation methods are important in order to provide a seedbed with an adequate contact between seed and moist soil (Känkänen et al. 2011). Annual variation in soil frost (Suppl. Fig. S1) also has an impact on water runoff, thereby contributing to soil erosion and nutrient leaching which are all enhanced by high winter-time precipitation (Rekolainen and Posch 1993). On the other hand, soil may be permeable even when frozen as macrospores are empty. Nonetheless, in mild winter the risk for nutrient leaching is higher than in cold winter (Puustinen et al. 2007). All these processes are further influenced by soil tillage methods (Puustinen et al. 2005, 2007, Soane et al. 2012).

Night frosts are particularly critical for crop production, though they also cause high annual variation in e.g. forest berry yields with many consequences on ecosystems. Many of the horticultural crops, fruit, berries and vegetables as well as potatoes (Solanum tuberosum L.) are very vulnerable to night frost (Lindén et al. 1999, Palonen and Lindén 2001, Kaukoranta et al. 2010). Therefore, irrigation in Finland is not only used to enhance the yields of these special cash-crops, but also to avoid frost damage (Peltonen-Sainio et al. 2015). Also, many field crops other than potatoes are sensitive to night frost (Lindén et al. 1999). Contrary to cereals that can tolerate night frost without seedling loss, spring rapeseed may face total seedling loss in the case of severe night frost $\left(\leq-9^{\circ} \mathrm{C}\right)$ while half of the seedlings are often lost in the case of $\leq-5^{\circ} \mathrm{C}$ night frost (Pahkala et al. 2006). However, field crop production farms do not currently have irrigation facilities, though they often have abundant water reserves next to their fields (Peltonen-Sainio et al. 2015), which as such protect from night frost to some extent (Solantie 1988). Night frost has, however, been a potentially increasing risk when considering that the cropping area of rapeseed has expanded from southern and south-coastal regions into more northerly latitudes (Peltonen-Sainio et al. 2009).

Night frost represents a risk to crop production virtually everywhere in Finland after the mean sowing time of main spring crops (Fig. 2). In the case of exceptionally early sowing (Table 2), the risk of night frost, and its severity increase dramatically. Furthermore, prior to sowing, in early spring, night frost may combine with daytime temperature that melts snow and thus causes frost heaving and root breakage of overwintering crops (Hofgaard et al. 2003).

Contrary to night frost in spring, in autumn freezing temperatures are not necessarily harmful, as they may sustain the acclimation of winter sown crops. They may also facilitate maize (Zea mays L.) quality and harvest for silage, though maize is only a novel, frost and chilling-sensitive minor crop tested by some farmers so far (probably encouraged by several warm summers in the 2000s). Night frost may cause quality problems such as high seed chlorophyll content for rapeseed. Night frost may occasionally occur at low frequencies also in the middle of summer, 
when it may in the most extreme cases destroy cereal heads and rapeseed flowers (Mukula and Rantanen 1989a, 1989b). This has not been experienced on a large scale for many decades until in 2014 night frost was observed e.g. in many regions of Pohjanmaa around heading of barley.

Autumn sown crops can escape from the stresses typical for spring sown crops, such as early summer drought and elevated temperatures (Peltonen-Sainio et al. 2011a) by having their root system in deep soil layers and having their most heat-vulnerable phenophases when the risk of heat waves is negligible (Peltonen-Sainio et al. 2016b). Some studies have shown that crop phenology has advanced faster than sowing times (Siebert and Ewert 2012), which may further increase the escape capacity of winter crops for elevated temperatures, but make them more prone to night frost. Nonetheless, autumn-sown crops are sensitive to harsh winter conditions that may even cause a total overwintering damage.

The weather constraint that most frequently caused overwintering damage for winter cereals in Finland, especially wheat, was cold spells that followed warm spells at any time outside the growing season (Peltonen-Sainio et al. 2011b). In the case of non-permeable soil frost, the thawing soil may freeze again and cause ice-encasement, which again causes anoxia (Lindén et al. 1999). This applies also to grassland and may shorten the lifespan, while in winter cereals it means re-sowing with some spring crop. Fluctuating temperature in winter and spring also causes a risk to shoots of fruit and berries (Lindén et al. 1999, Kaukoranta et al. 2010). Nonetheless, fluctuating warm and cold spells outside the growing season are common and occurred two to three times per decade in north-west coastal regions of Finland as well as in eastern inland regions (Fig. 3). In the other regions, the likelihood was from 10 to $15 \%$, except in the archipelago with negligible risks.

Climate warming is advancing most in the northern, high latitude regions of the globe, and winters are warming more than summers (IPCC 2013). This is projected to associate with fewer days with frost and snow, a longer frostfree season and a smaller liquid water equivalent of snow (Jylhä et al. 2008). Snow cover in the Northern Hemisphere has already declined during recent decades (Walsh et al. 2005). As snow and ice constitute an important climatic feedback mechanism, they regulate seasonal transitions in the annual cycle. Jylhä et al. (2008) estimated that the frost seasons will become more diffuse in many northern regions of Europe including Finland.

In the case that winter conditions are going to be more variable in the future as projected (Jylhä et al. 2008, IPCC 2012), the timing of agricultural operations and overwintering of autumn sown and perennial crops may be challenged. High variability in winter conditions may decelerate the shift from spring- to autumn-sown crops despite many ecosystem services (e.g. a reduction in soil erosion and nutrient leaching) that overwintering crops might provide for the future agro-ecosystems. Many technological developments have taken place during recent decades in agriculture and especially so regarding soil tillage and sowing methods that were partly driven by the elementary changes in socio-economic situations of the farms caused by EU Common Agricultural Policy. Not only following technological achievements but also due to already experienced climate warming, sowing of spring cereals in Finland has advanced by 0.6-1.7 days per decade depending on region (Kaukoranta and Hakala 2008). In sugar beet and potatoes, sowing and planting have advanced more than expected due to climate warming, which again highlights the contribution of technological development: by 2.5 days for sugar beet and 3.4 days for potatoes with even an increasing pace of advancement since 1980s (Kaukoranta and Hakala 2008). In addition to this, farmers have shifted from early to later maturing cultivars and crops as a response to past conditions, though they also may make an opposite shift after a cool growing season (Peltonen-Sainio et al. 2013).

The projections of Jylhä et al. (2008) indicate that the soil frost period will get shorter in the future, which has profound impacts on agro-ecosystems and agricultural practices. It is possible that, despite climate warming, the risk of night frost will not ease off or get worse, if the spring sowing time (or onset of spring growth of overwintering crops) advances parallel to the shift in the timing of the last severe night frost in spring (see e.g. Gregory and Marshall 2012). This agrees with the future projections of unchanged frost risk for flowering in apples in most of Finland, though some regional differences in frost risk were also seen (Kaukoranta et al. 2010). Contrary to the findings in Finland, according to van Oort et al. (2012) the temperature elevation as such is not the main driver of earlier sowing: farmers have not advanced sowing of sugar beet in the Netherlands, but sowing has taken place in higher temperature conditions when farmers have waited to have a sufficiently high number of frost days sustaining seedbed preparation. 


\section{Conclusions}

This sub-paper of this trilogy underlines the high risks related to night frost in boreal agricultural regions of Europe. Especially many cash-crops, both horticultural and field crops, are vulnerable to frost-induced losses and failures. Furthermore, depending on winter conditions, variation in soil frost is high, as is also the timing of sowings in spring. With this paper, we also demonstrate the risk of late snow cover as well as greatly fluctuating winter conditions, the latter causing overwintering damages of autumn sown and perennial crops. Again, the data that are shown in this paper may have many other applications beyond the assessments on some agricultural operations that are highlighted here.

\section{Acknowledgements}

The work was financed by the Ministry of Agriculture and Forestry and Natural Resources Institute Finland (Luke) as a part of a consortium project entitled Improving Resilience to Climate Change and Variation Induced Risks in Agriculture (ILMAPUSKURI).

\section{References}

Aalto, J., Pirinen, P., Heikkinen, J. \& Venäläinen, A. 2013. Spatial interpolation of monthly climate data for Finland: comparing the performance of kriging and generalized additive models. Theoretical \& Applied Climatology 112: 99-111.

Edwards, L.M. 2013. The effects of soil freeze-thaw on soil aggregate breakdown and concomitant sediment flow in Prince Edward Island: A review. Canadian Journal of Soil Science 93: 459-472.

Gregory, P.J. \& Marshall, B. 2012. Attribution of climate change: a methodology to estimate the potential contribution to increases in potato yield in Scotland since 1960. Global Change Biology 18: 1372-1388.

Hakala, K., Jauhiainen, L., Himanen, S., Rötter, R., Salo, T. \& Kahiluoto, H. 2012. Sensitivity of barley varieties to weather in Finland. Journal of Agricultural Science 150: 145-160.

Hofgaard, I.S., Vollsnes, A.V., Marum, P., Larsen, A. \& Tronsmo, A.M. 2003. Variation in resistance to different winter stress factors within a full-sib family of perennial ryegrass. Euphytica 134: 61-75.

Huttunen, L. \& Soveri, J. 1993. Luonnontilaisen roudan alueellinen ja ajallinen vaihtelu Suomessa. (The regional and temporal variation of frost in natural conditions in Finland.) Abstract. Publications of the National Board of Waters and the Environment Ser A 139. 74 p.

IPCC 2012. Summary for Policymakers. In: Field, C.B., Barros, W., Stocker, T.F., Qin, D., Dokken, D.J., Ebi, K.L., Mastrandrea, M.D., Mach, K.J., Plattner, G.-K., Allen, S.K., Tignor, M. \& Midgley, P.M., (eds). Managing the Risks of Extreme Events and Disasters to Advance Climate Change Adaptation. A Special Report of Working Groups I and II of the Intergovernmental Panel on Climate Change, Cambridge: Cambridge University Press. 19 p.

IPCC 2013. Summary for Policymakers. In: Stocker T.F., Qin D., Plattner G.-K., Tignor M., Allen S.K., Boschung J., Nauels A., Xia Y., Bex V. \& Midgley P.M. (eds). Climate Change 2013: The Physical Science Basis. Contribution of Working Group I to the Fifth Assessment Report of the Intergovernmental Panel on Climate Change, Cambridge: Cambridge University Press. 28 p.

Jylhä, K., Fronzek, S., Tuomenvirta, H., Carter, T.R. \& Ruosteenoja, K. 2008. Changes in frost, snow and Baltic sea ice by the end of the twenty-first century based on climate model projections for Europe. Climatic Change 86: 441-462.

Kaukoranta, T. \& Hakala, K. 2008. Impact of spring warming on sowing times of cereal, potato and sugar beet. Agricultural and Food Science 17: 165-176.

Kaukoranta, T., Tahvonen, R. \& Ylämäki, A. 2010. Climatic potential and risks for apple growing by 2040. Agricultural and Food Science 19: 144-159.

Känkänen, H., Alakukku, L., Salo, Y. \& Pitkänen, T. 2011. Growth and yield of spring cereals during transition to zero tillage on clay soils. European Journal of Agronomy 34: 35-45.

Lilja, H., Uusitalo, R., Yli-Halla, M., Nevalainen, R., Väänänen, T. \& Tamminen, P. 2009. Suomen Maannostietokanta. MTT TIEDE 6. 69 p. Helsinki, Finland. (In Finnish with English abstract).

Lindén, L., Palonen, P. \& Seppänen, M. 1999. Cold hardiness research on agricultural and horticultural crops in Finland. Agricultural and Food Science in Finland 8: 459-477.

Mukula, J.\& Rantanen, O. 1989a. Climatic risks to the yield and quality of field crops in Finland. III. Winter rye 1969-1986. Annals Agriculturae Fenniae 28: 3-11.

Mukula, J.\& Rantanen, O. 1989b. Climatic risks to the yield and quality of field crops in Finland. VI. Barley 1969-1986. Annals Agriculturae Fenniae 28: 29-36.

Niemi, J. \& Ahstedt, J. 2011. Finnish Agriculture and Rural Industries 2011. Agrifood Research Finland, Economic Research, Publications 111a. $96 \mathrm{p}$.

Oort, van, P.A.J., Timmermans, B.G.H. \& Swaaij, van, A.C.P.M. 2012. Why farmers' sowing dates hardly change when temperature rises. European Journal of Agronomy 40: 102-111. 
Pahkala, K., Känkänen, H., Peltonen-Sainio, P. \& Huusela-Veistola, E. 2006. Rypsin itämisen ja kasvuun lähdön edistäminen. In: Rantamäki-Lahtinen L., Partanen K. (eds). Esitelmä- ja posteritiivistelmät, Maataloustieteen Päivät 2006, Helsinki. (In Finnish).

Palonen, P. \& Linden, L. 2001. Winter hardiness of micropropagated and conventionally propagated strawberry plants. Journal of Horticultural Science \& Biotechnology 76: 685-690.

Peltonen-Sainio, P., Hakala, K. \& Jauhiainen, L. 2011b. Climate induced overwintering challenges for wheat and rye in northern agriculture. Acta Agriculturae Scandinavica, B Soil and Plant Science 61: 75-83.

Peltonen-Sainio, P. \& Jauhiainen, L. 2014. Lessons from the past in weather variability: sowing to ripening dynamics and yield penalties for northern agriculture in 1970-2012. Regional Environmental Change 14: 1505-1516.

Peltonen-Sainio, P., Jauhiainen, L. \& Hakala, K. 2011a. Crop responses to temperature and precipitation according to long-term multi-location trials at high-latitude conditions. Journal of Agricultural Science 149: 49-62.

Peltonen-Sainio, P., Jauhiainen, L., Niemi, J.K., Hakala, K. \& Sipiläinen, T. 2013. Do farmers rapidly adapt to past growing conditions by sowing different proportions of early and late maturing cereals and cultivars? Agricultural and Food Science 22: 331-341.

Peltonen-Sainio, P., Jauhiainen, L. \& Venäläinen, A. 2009. Comparing regional risks in producing turnip rape and oilseed rape - Today in light of long-term datasets. Acta Agriculturae Scandinavica, B Soil and Plant Science 59: 118-128.

Peltonen-Sainio, P., Laurila, H., Jauhiainen, L. \& Alakukku, L. 2015. Proximity of waterways to Finnish farmlands and associated characteristics of regional land use. Agricultural and Food Science 24: 24-38.

Peltonen-Sainio, P. \& Niemi, J.K. 2012. Protein crop production at the northern margin of farming: To boost, or not to boost. Agricultural and Food Science 21: 370-383.

Peltonen-Sainio, P., Pirinen, P., Mäkelä, H.M., Hyvärinen, O., Huusela-Veistola, E., Ojanen, H. \& Venäläinen, A. 2016b. Spatial and temporal variation in weather events critical for boreal agriculture: I Elevated temperatures. Agricultural and Food Science 25: 44-56.

Peltonen-Sainio, P., Pirinen, P., Mäkelä, Ojanen, H. \& Venäläinen, A. 2016c. Spatial and temporal variation in weather events critical for boreal agriculture: II Precipitation. Agricultural and Food Science 25: 57-70.

Peltonen-Sainio, P. \& Rajala, A. 2007. Duration of vegetative and generative development phases in oat cultivars released since 1921. Field Crops Research 101: 72-79.

Peltonen-Sainio, P., Venäläinen, A., Mäkelä, H.M., Pirinen, P., Laapas, M., Jauhiainen, L., Kaseva, J., Ojanen, H., Korhonen, P., Huusela-Veistola, E., Jalli, M., Hakala, K., Kaukoranta, T. \& Virkajärvi, P. 2016a. Harmfulness of weather events and adaptive capacity of farmers at high latitudes of Europe. Climate Research 67: 221-240. DOI: 10.3354/cr01378.

Pirinen, P., Simola, H., Aalto, J., Kaukoranta, J.-P., Karlsson, P. \& Ruuhela, R. 2012. Climatological statistics of Finland 1981-2010. Finnish Meteorological Institute Reports 1.83 p.

Puustinen, M., Koskiaho, J. \& Peltonen, K. 2005. Influence of cultivation methods on suspended solids and phosphorus concentrations in surface runoff on clayey sloped fields in boreal climate. Agriculture, Ecosystems and Environment 105: 565-579.

Puustinen, M., Tattari, S., Koskiaho, J. \& Linjama, J. 2007. Influence of seasonal and annual variations on erosion and phosphorus transport from arable areas in Finland. Soil \& Tillage Research 93: 44-55.

Rajala, A., Niskanen, M., Isolahti, M. \& Peltonen-Sainio, P. 2011. Seed quality effects on seedling emergence, plant stand establishment and grain yield in two-row barley. Agricultural and Food Science 20: 228-234.

Rekolainen, S. \& Posch, M. 1993. Adapting the CREAMS model for Finnish conditions. Nordic Hydrology 24: 309-322.

Siebert, S. \& Ewert, F. 2012. Spatio-temporal patterns of phonological development in Germany in relation to temperature and day length. Agricultural and Forest Meteorology 152: 44-57.

Soane, B.D., Ball, B.C., Arvidsson, J., Basch, G., Moreno, F. \& Roger-Estrade, J. 2012. No-till in northern, western and south-western Europe: A review of problems and opportunities for crop production and the environment. Soil \& Tillage Research 118: 66-87.

Solantie, R. 1988. Climatic conditions for the cultivation of rye with reference to the history of settlement in Finland. Fennoscandia Archaeological 5: 3-20.

Walsh, J.E., Anisimov, O., Hagen, J.O.M., Jakobsson, T., Oerlemans, J., Prowse, T.D., Romanovsky, V., Savelieva, N., Serreze, M., Shiklomanov, I. \& Solomon, S. 2005. Cryophere and hydrology. In: Symon, C., Arris, L. \& Heal, B. (eds). Arctic Climate Impact Assessment. Cambridge, UK: Cambridge University Press. p. 183-242.

Venäläinen, A., Tuomenvirta, H., Lahtinen, R. \& Heikinheimo, M. 2001. The influence of climate warming on soil frost in case of snow-free surfaces in Finland. Climatic Change 50: 111-128. 